\title{
The Effects of Additives on the Quality and Nutritive Value of Packed Silage
}

\author{
Kyuei KiBE \\ (Laboratory of Animal Nutrition, Faculty of Agriculture, \\ Shinshu University, Ina, Japan) \\ (Received for Publication on February 7, 1966)
}

The losses during ensiling process are due to the action of respiration, fermentation, surface spoilage and seepage of the mass. As to the fermentation, LANGsToN et al. ${ }^{6)}$ showed that during the early stages of fermentation a degree of aeration of forage markedly influenced the bacterial flora and the chemical quality of the silage examined. Moreover, by WIERINGA et $=$ al. ${ }^{32}$, it was proved that the grass under anaerobic conditions gave a silage of good quality, but an aeration and a high temperature (above $40^{\circ} \mathrm{C}$ ) in the silage ensiling material caused a fixation of protein, a decrease in lactic acid formation and an increase in production of unfavorable ammonia, butyric or acetic acid.

Several workers proved that the quality of silage made with additives was much better than that of the conventional silage. Recently, the various additives such as acids, carbohydrates and antiseptic agents were widely used for the purpose of stimulating the development of desirable bacteria or checking the growth of putrefactive organisms.

As a conservating container, tower silo is ordinarily used but it is recognized that the losses in dry matter and nutritive value of the silage sometimes increases to a considerable extent by fermentation, spoilage and seepage.

It is considered that applying polyethylene film bags for ensiling forage materials can serve to make condition of fermentation more anaerobic, and some wilting of very succulent forages before ensiling is not needed by adding of absorbent agent such as starch. Moreover, the packed silage may be more convenient to handle and to feed than ordinary silage.

The present investigation was undertaken to clarify the effects of polyethylene film bags used as a container and of various additives on the quality and on the nutritive value of silages.

\section{Materials and Methods}

\section{Packed silage preparation}

This paper describes three trials to investigate the changes on the quality of silages prepared from three different kinds of materials and of different treatments, as are shown in Table 1.

In this experiment bags of polyethylene film $(0.06 \mathrm{~mm}$ thick, $10 \mathrm{~cm}$ in diam. $\times 30 \mathrm{~cm}$ high in trial 1 and $2 ; 0.08 \mathrm{~mm}$ thick, $30 \mathrm{~cm}$ in diam. $\times 60 \mathrm{~cm}$ high in trial 3 ) were used for packing 
KIBE

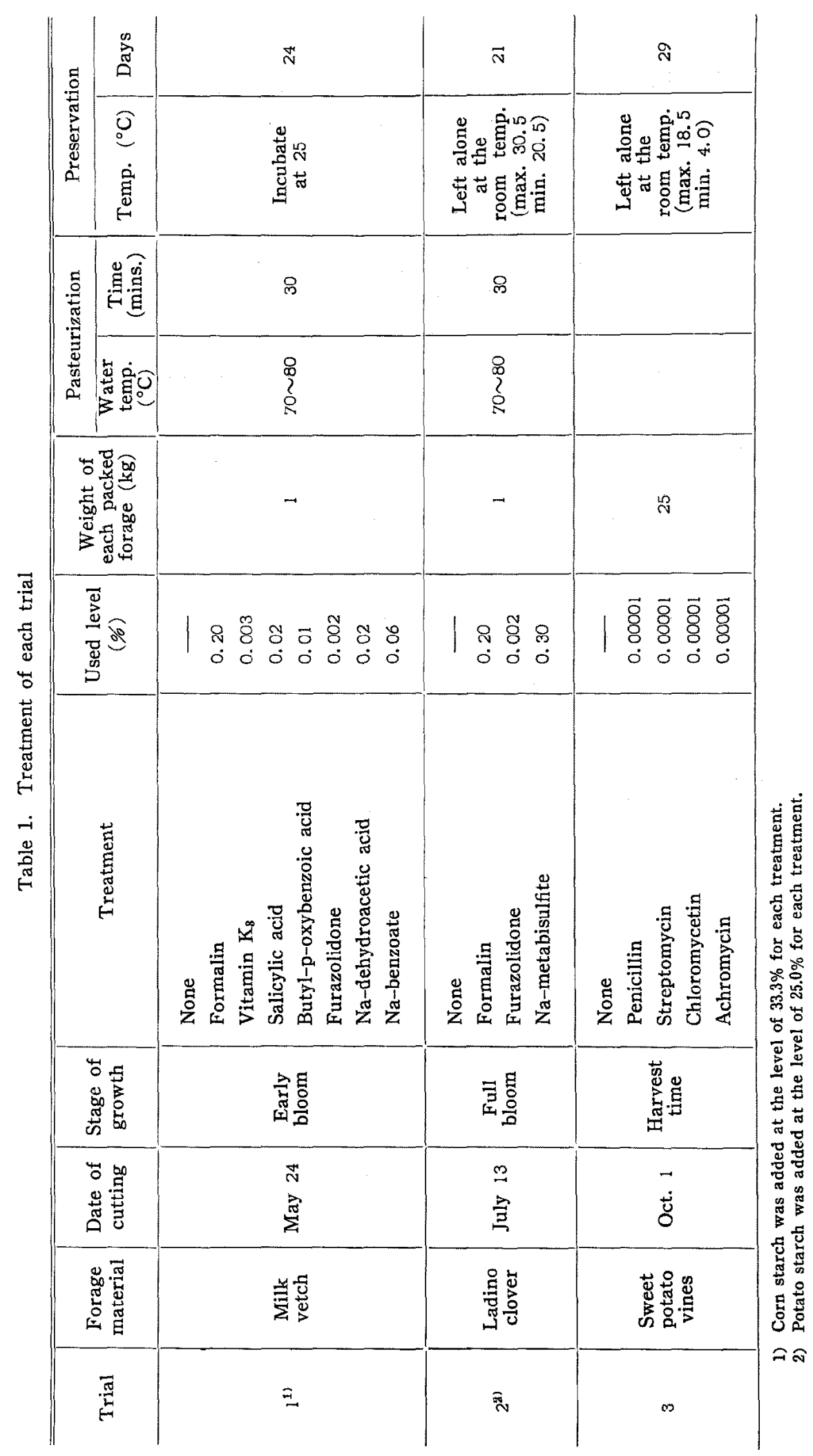


materials to keep the anaerobic conditions of packed materials. In trial 1, corn starch was added at the level of 33.3 percent, and in trial 2, potato starch was added at the level of 25. 0 percent for each treatment respectively, but in trial 3 starch was not used. The additives were added to green stuffs to preserve its qualities or to control acid fermentation. The level of these additives used was determined within the allowance of the food sanitary control except formalin, furazolidone and antibiotics. Formalin was applied on the low level of 0.2 percent, because it can be highly toxic even in small amounts. Furazolidone was used at the level of prophylactic dose, and the used dose of antibiotics was also on the normal level. The stuffed bags were tied fast with the linen thread, and then the packed forages were pasteurized in hot water before conservation in order to regulate the bacterial and enzymatic action during the early stages of fermentation. The process of packing and preserving forages was as follows.

\section{Packing Process of Forage}

Green forage material $\longrightarrow$ Chopping and bruising $\longrightarrow$ Mixing with additives (starch, antiseptics or antibiotics $>$ Stirring $\longrightarrow$ Packing in bags $\longrightarrow$ Sealing with thread $\longrightarrow$ Pasteurization $\left(70 \sim 80^{\circ} \mathrm{C}, 30 \mathrm{~min}\right.$. $) \longrightarrow$ Conservation.

\section{Chemical analyses}

Chemecal analysis were accomplished as follows: a) Ten $\mathrm{g}$ samples of silage were macerated in a WARING blendor for 10 minutes with about $50 \mathrm{~m} l$ distilled water, and the transparent solutions were then filled up at $250 \mathrm{~m} l$ after centrifugation. b) Dry matter of the silage was determined after drying in an oven at $105^{\circ} \mathrm{C}$ for about three hours. c) The $\mathrm{pH}$ was determined by the Hitachi $\mathrm{pH}$ meter $\mathrm{M}-3$. d) Total and steamed volatile fatty acids were determined by titration ${ }^{11}$. Amount of non-volatile fatty acids was calculated by the deduction of volatile fatty acids from total acids, and volatile fatty acid was represented as acetic acid and non-volatile fatty acid was represented as lactic acid. e) Total nitrogen was determined by the KYELDAHL method ${ }^{2}$ and ammonia nitrogen was determined by the diffusion method of ConwaY ${ }^{8)}$. Amino nitrogen was determined by the VAN SLYKE manometric method").

\section{Digestion trials}

In order to compare the digestibility and protein utilization of the packed silage, 12 male rabbits of about 2 kilograms of body weight were allocated at random to 6 treatments as

Table 2. The silage samples used in digestion trials

\begin{tabular}{c|l}
\hline Trial & \multicolumn{1}{c}{$\begin{array}{c}\text { Silage samples treated with } \\
\text { additives }\end{array}$} \\
\hline \multirow{3}{*}{1} & $\begin{array}{l}\text { None } \\
\text { Formalin } \\
\text { Furazolidone } \\
\text { Na-metabisulfite }\end{array}$ \\
\hline \multirow{2}{*}{2} & $\begin{array}{l}\text { None } \\
\text { Streptomycin }\end{array}$ \\
\hline
\end{tabular}

The silage samples in trial 1 and 2 are the same ones that were used in trial 2 and 3 at Table 1 respectively. 
shown in Table 2. All rabbits were kept in the individual metabolism cages throughout the experimental period. The silage samples in each treatment were stored in freezing box until they were used in feeding. After 10 days' preliminary feeding of the respective silage samples from each treatment, silage, feces and urine samples were weighed and measured daily for 7 days. In each treatment of trial 1, the silage was fed once daily. And in trial 2, 13 percent of wheat bran was added to the silage samples of each treatment, so the data of the digestibility, T.D.N. and biological value ${ }^{71}$ of protein in trial 2 indicate the values of the combined biet of packed silage plus wheat bran.

\section{Results and Discussion}

It is well recognized that in most cases, the high moisture content of the herbage material tends to decrease the quality and nutritive value of the products. In order to reduce the high moisture content in such succulent herbage, starch was used as an abesorbent agnt in this experiment. Moreover, by bruising and stuffing with chopper, macerated forages were compactly put into the bags. Thus, it is evident that the starch serves as an energy source for the animal, besides it fills up the mass and serves also as a food for microfiora.

A subjective evaluation of silage in appearance and odour was fairly high. Average dry matter and organic acids content and also $\mathrm{pH}$ value of the silages are shown in Table 3.

In trial 1 , the addition of various conservatives except formalin and furazolidone had little

Table 3. The $\mathrm{pH}$, dry matter and organic acid concentration of packed silages

\begin{tabular}{|c|c|c|c|c|c|c|}
\hline \multirow[b]{2}{*}{ Trial } & \multirow[b]{2}{*}{ Treatment } & \multirow[b]{2}{*}{$\mathrm{pH}$} & \multirow[b]{2}{*}{$\begin{array}{l}\text { D.M. } \\
(\%)\end{array}$} & \multicolumn{3}{|c|}{ Percent on dry matter basis } \\
\hline & & & & Total acids & $\begin{array}{c}\text { Steamed } \\
\text { volatile } \\
\text { acids }\end{array}$ & $\begin{array}{c}\text { Non- } \\
\text { volatile } \\
\text { acids }\end{array}$ \\
\hline \multirow{8}{*}{1} & None & 5.00 & 36.8 & $0.54(100)$ & $0.31(57.4)$ & $0.23(42.6)$ \\
\hline & Formalin & 5.94 & 36.1 & $0.14(100)$ & $0.07(50.0)$ & $0.07(50.0)$ \\
\hline & Vitamin $\mathrm{K}_{\mathbf{3}}$ & 4.78 & 35.1 & $0.85(100)$ & $0.69(81.2)$ & $0.16(18.8)$ \\
\hline & Salicylic acid & 5.07 & 35.5 & $0.51(100)$ & $0.32(62.7)$ & $0.19(37.3)$ \\
\hline & Butyl-p-oxybenzoic acid & 4.61 & 32.1 & $1.21(100)$ & $0.98(81.0)$ & $0.23(19.0)$ \\
\hline & Furazolidone & 6.01 & 33.7 & $0.09(100)$ & $0.09(100.0)$ & $-(0.0)$ \\
\hline & No-dehydroacetic acid & 4.87 & 33.1 & $0.97(100)$ & $0.95(97.9)$ & $0.02(2.1)$ \\
\hline & No-benzoate & 4.95 & 38.1 & $0.58(100)$ & $0.37(63.8)$ & $0.21(36.2)$ \\
\hline \multirow{4}{*}{2} & None & 4.16 & 36.3 & $2.89(100)$ & $1.72(59.5)$ & $1.17(40.5)$ \\
\hline & Formalin & 4.20 & 38.8 & $1.65(100)$ & $0.65(39.4)$ & $1.00(60.6)$ \\
\hline & Furazolidone & 4.20 & 32.8 & $2.65(100)$ & $0.86(32.5)$ & $1.79(67.5)$ \\
\hline & Na-metabisulfite & 4.60 & 37.2 & $1.85(100)$ & $0.56(30.3)$ & $1.29(69.7)$ \\
\hline \multirow{5}{*}{3} & None & 3.87 & 14,5 & $5.86(100)$ & $1.20(20.5)$ & $4.66(79.5)$ \\
\hline & Penicillin & 4.01 & 9.1 & $7.47(100)$ & $2.20(29.5)$ & $5.27(70.5)$ \\
\hline & Streptomycin & 4.01 & 11.3 & $5.84(100)$ & $1.97(33.7)$ & 3. $87(66.3)$ \\
\hline & Chloromycetin & 4.00 & 12.0 & $6.67(100)$ & $1.83(24.4)$ & $4.84(75.6)$ \\
\hline & Achromycin & 3.88 & 11.3 & $8.23(100)$ & $1.84(22.4)$ & $6.39(77.6)$ \\
\hline
\end{tabular}




\section{Influence of additives on packed silage}

effect on $\mathrm{pH}$ and on the total acids. On the other hand, treatments with formalin and furozolidone considerably reduced the acid production. The results showed that both additives had a sterilizing property for the bacterial flora of the silages. From the results mentioned above, the 2 nd trial has been conducted for the purpose of testing again the effects of formalin and furazolidone on the silage fermentations. In addition, the effect of well-known sodium metabisulfite was tested, too.

The $\mathrm{pH}$ value in the mass is usually influenced by organic acids and ammonia nitrogen. In trial $2, \mathrm{pH}$ value of the mass added sodium metabisulfite was slightly higher than that of the other three groups.

Table 4. Nitrogen distribution in water soluble part of the packed silages

\begin{tabular}{|c|c|c|c|c|c|c|}
\hline \multirow{3}{*}{ Trial } & \multirow{3}{*}{ Treatment } & \multicolumn{5}{|c|}{ In water soluble part } \\
\hline & & \multirow{2}{*}{$\begin{array}{c}\text { Total } \\
\text { nitrogen } \\
\text { as \% of } \\
\text { D.M. }\end{array}$} & \multicolumn{2}{|c|}{ Amino nitrogen } & \multicolumn{2}{|c|}{ Ammonia nitrogen } \\
\hline & & & $\begin{array}{l}\text { as } \% \text { of } \\
\text { D.M. }\end{array}$ & $\begin{array}{c}\text { as } \% \text { of } \\
\text { T.N. }\end{array}$ & $\begin{array}{c}\text { as } \% \text { of } \\
\text { D.M. }\end{array}$ & $\begin{array}{l}\text { as \% of } \\
\text { T.N. }\end{array}$ \\
\hline \multirow{8}{*}{1} & None & 0.730 & 0.242 & 33.2 & 0.0432 & 5.91 \\
\hline & Formalin & 0.679 & 0.313 & 46.1 & 0.0440 & 6.48 \\
\hline & Vitamin $\mathrm{K}_{s}$ & 0.744 & 0.436 & 58.6 & 0.0509 & 6.84 \\
\hline & Salicylic acid & 0.634 & 0.223 & 35.2 & 0.0389 & 6.14 \\
\hline & Butyl-p-oxybenzoic acid & 0.729 & 0.231 & 31.7 & 0.0707 & 9.70 \\
\hline & Furazolidone & 0.674 & 0.320 & 47.5 & 0.0368 & 5.46 \\
\hline & Na-dehydroacetic acid & 0.701 & 0.284 & 40.5 & 0.0583 & 8.32 \\
\hline & Na-benzoate & 0.727 & 0.415 & 57.1 & 0.0488 & 6.71 \\
\hline \multirow{4}{*}{2} & None & 1.683 & 0.435 & 25.8 & 0.0950 & 5.64 \\
\hline & Formalin & 1.464 & 0.611 & 41.7 & 0.0889 & 6.07 \\
\hline & Furazolidone & 2.021 & 0.421 & 20.8 & 0.1155 & 5.71 \\
\hline & Na-metabisulfite & 1.724 & 0.384 & 22.0 & 0.1761 & 10.08 \\
\hline \multirow{5}{*}{3} & None & 3.055 & 0.579 & 19.0 & 0.0669 & 2.19 \\
\hline & Penicillin & 3.406 & 1.956 & 57.4 & 0.1670 & 4.90 \\
\hline & Streptomycin & 3.026 & 1.088 & 36.0 & 0.1035 & 3.42 \\
\hline & Chloromycetin & 3.250 & 1.358 & 41.8 & 0.1666 & 5.13 \\
\hline & Achromycin & 3.071 & 0.832 & 27.1 & 0.1221 & 3.97 \\
\hline
\end{tabular}

From the figures in Table 3 and 4, it is observed that the $\mathrm{pH}$ value of the silages was more strongly affected by ammonia nitrogen than by organic acids. In comparing trial 1 and 2 , it is interesting that the acid production was not only influenced by the environmental temperature of the silages but also by the seasonal difference of the kind of bacteria and by the difference of the kind of forages. Acid producing bacteria were more developed in the temperature ranging from 20.5 to $30.5^{\circ} \mathrm{C}$ in warmer season than in the case of the constant temperature of $25^{\circ} \mathrm{C}$ in the cool season. In trial 3 , the $\mathrm{pH}$ values were also quite similar in all treatments, but the acid production levelwas several times as high as the level in trial 1 or 2. In particular, non-volatile acid production in trial3 has remarkably developed. The data indicate that the advna tage in controlling the acid production in trial 1 or 2 can be 
attributed to the hot-water pasteurization. In trial 1 , the content of total acids in the silage treated with butyl-p-oxybenzoic acid was very high, but whether this high value is attributable to the action of butyl-p-oxybenzoic acid or to any other factors, the reason could not be clarified. According to the work on the microbial flora of the silages by $\mathrm{O}_{\mathrm{CH}}$ et al. ${ }^{8}$, the addition of bacitracin had little effects on the microbial changes. And in the experiments of this paper on the acid production, the use of antibiotics (penicillin, streptomycin, chloromycetin and achromycin) has little effect on the fermentation process of silages.

Results of the digestion trials are shown in Table 5, 6, and 7. From the data it was found that the addition of sodium metabisulfite did not interfere with the digestibility and the protein utilization of packed silages, but the addition of both formalin and furazolidone depreciated materially the digestibilities of all nutrients. And the addition of streptomycin also reduced the total digestible nutrients of silages. In consideration of these results, it may be concluded that the above-stated disturbances in digestion have occurred, because of unfavourable denaturation of the protein and other nutrients by formalin addition on the one side, and because of inhibition of microbial function by furazolidone and streptomycin addition on the other side. But, in general, the data of apparent digestibility of protein in this survey were similar or relatively high in comparison with the data of Lanors ${ }^{6}$ ) and also with the data on wether lambs by Hidirogiou et al.4. It is, therefore, that the anaerobic heating at high

Table 5. Chemical composition of packed silages and wheat bran (\%)

\begin{tabular}{c|l|c|c|c|c|c|c}
\hline \hline Trial & Treatment & Moisture & $\begin{array}{c}\text { Crude } \\
\text { protein }\end{array}$ & $\begin{array}{c}\text { Crude } \\
\text { fat }\end{array}$ & $\begin{array}{c}\text { Crude } \\
\text { fiber }\end{array}$ & $\begin{array}{c}\text { Crude } \\
\text { ash }\end{array}$ & N.F.E. \\
\hline \multirow{5}{*}{1} & None & 63.70 & 3.81 & 1.00 & 3.07 & 2.05 & 26.37 \\
& Formalin & 61.50 & 4.15 & 1.08 & 3.27 & 2.12 & 27.88 \\
& Furazolidone & 67.21 & 3.55 & 0.89 & 2.84 & 1.83 & 23.68 \\
& Na-metabisulfite & 62.80 & 4.05 & 1.04 & 2.95 & 2.13 & 27.02 \\
\hline \multirow{5}{*}{2} & None & 85.61 & 2.75 & 0.32 & 3.07 & 2.05 & 6.20 \\
& Streptomycin & 88.60 & 2.14 & 0.31 & 2.91 & 1.44 & 4.60 \\
& Wheat bran ${ }^{13}$ & 14.67 & 16.63 & 2.00 & 10.00 & 4.90 & 51.80 \\
\hline
\end{tabular}

1) 13 percent of wheat bran was supplemented to the packed silage of each treatment in trial 2.

Table 6. Apparent digestibility of some nutrients and T.D.N. of packed silages (\%)

\begin{tabular}{|c|c|c|c|c|c|c|c|}
\hline \multirow{2}{*}{ Trial } & \multirow{2}{*}{ Treatment } & \multicolumn{5}{|c|}{ Apparent digestibility } & \multirow{2}{*}{ T.D.N. } \\
\hline & & $\begin{array}{l}\text { Crude } \\
\text { protein }\end{array}$ & $\begin{array}{c}\text { Crude } \\
\text { fat }\end{array}$ & $\begin{array}{c}\text { Crude } \\
\text { fiber }\end{array}$ & $\begin{array}{c}\text { Crude } \\
\text { ash }\end{array}$ & N.F.E. & \\
\hline \multirow{4}{*}{1} & None & 67.2 & 74.4 & 60.6 & 69.3 & 83.4 & 77.5 \\
\hline & Formalin & 62.5 & 48.9 & 40.1 & 67.7 & 72.4 & 65.6 \\
\hline & Furazolidone & 64.3 & 52.1 & 19.7 & 62.9 & 66.5 & 63.3 \\
\hline & Na-metabisulfite & 69.0 & 68.3 & 37.8 & 70.7 & 84.6 & 76.2 \\
\hline \multirow{2}{*}{2} & None & 64.7 & 43.2 & -2.9 & 48.2 & 51.1 & 40,4 \\
\hline & Streptomycin & 60.2 & 63.8 & 2.6 & 27.0 & 43.5 & 37.7 \\
\hline
\end{tabular}

The data are indicated on the average of two rabbits. 
Influence of additives on packed silage

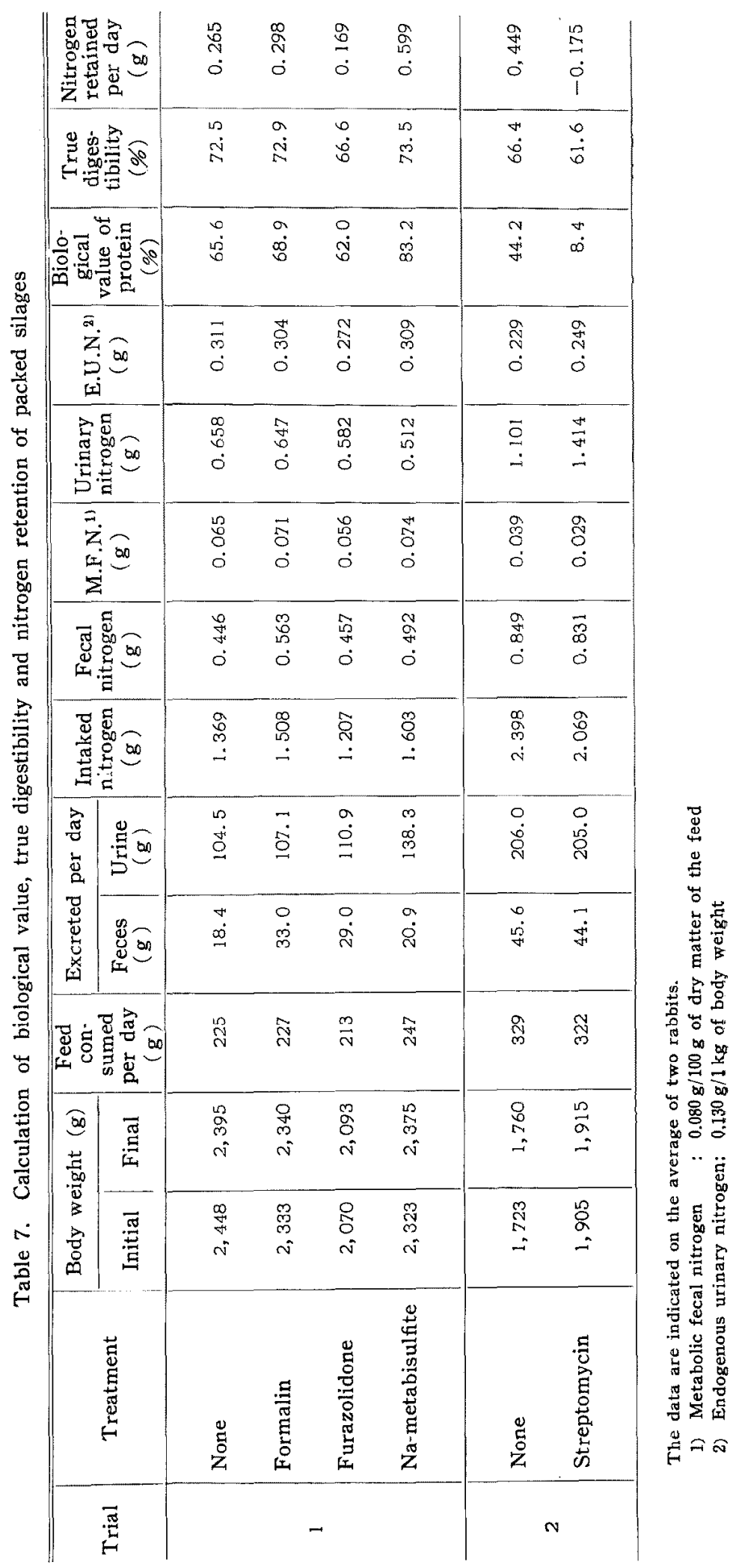


temperature for short time sterilization preceding to the preservation did not reduce the protein digestibility.

In Table 7, it can be seen that the biological values of silage samples have varied in proportion to the nitrogen retained. Especially, in the case of sodium metabisulfite treatment both the biological value and the nitrogen retention were very high, but the reason for this high level was not clarified. And, it is also unknown that whether the depression of the biological value of streptomycin treatment is due to the condition of animal disorder or to any other factors.

\section{Summary}

Three trials were conducted to investigate the effects of additives on the quality and nutritive value of packed silage.

Among various additives, formalin, furazolidone and sodium metabisulfite were effective to a certain extent for the control of silage fermentation. From the results of digestion trial, however, it was found that the addition of sodium metabisulfite did not interfere with the digestibility and protein utilization of packed silages, but the addition of both formalin and furazolidone depreciated materially the digestibilities of all nutrients. Moreover, it appears that the use of antibiotics (penicillin, streptomycin, chloromycetin and achromycin) has little effect on the fermentation process of the silage.

The results reported above suggest the short time anaerobic heating at high temperature for pasteurization preceding to the preservation did not reduce the protein digestibility, but depressed the acid production of packed silages.

The polyethylene film bag as a container was successfully used to maintain the anaerobic condition during fermentation process.

\section{Acknowledgements}

The author wishes to thank Dr. M. Kanematsu, Professor of this University, and Dr. M. Sato, Professor of Nihon University, and Dr. I. TASAKI, Professor of Nagoya University, and Mr.

K. SekiKaWA, Assistant of this University for many helpful discussion and suggestions during this work, and also Mr. K. Amano and Mr. T. Shibata for their excellen ttechnical assistance.

\section{References}

1) A.O.A.C. (1960) 9 th ed. 112, 143, 300. A.O.A.C. Washington 4, D.C.

2) Clark, E.P. (1943) Semi-Micro Quantitative Organic Analysis 42. Academic Press. New York.

3) ConwaY, E.J. (1950) Microdiffusion Analysis and Volumetric Error 3 rd ed. 95 96. Crosby Lockwood \& Son Ltd. London.

4) Hidiroglou, M., J.L. Tessier and P. Dermine (1965) J. Brit. Grassl. Soc., 20:59 63.

5) Landis, J. (1960) Proceeding of the Eighth International Grassland Congress $625 \sim 628$. Eighth International Grassland Congress, Reading, Berkshire, England.

6) Langston, C.W., C. Bouma and R.M. Conner (1962) J. Dairy Sci., 45:618 624.

7) Mrtchell, H.H. (1924) J. Biol. Chem., 58:873.

8) Ochi, Y., T. Mitsuoka, T. Sega, T. Ikegami and T. Mrura (1965) Jap. J. Zootech. Sci., $36: 353 \sim 357$.

9) Wieringa, G.W., S. Schukking, D. Kappelle and SJ. De HaAn (1961) Neth. J. Agric. Sci., 9:210 216. 


\title{
包装サイレージの品質ならびに栄養価值におよぼす 添加戍の効果について
}

\author{
木部久衛 \\ (信州大学農学部)
}

種ヶの添加凪がサイレージの品質ならびにその栄蕉価 值におよ活す影響を調查する目的で本実験を行なった。

まず，磨砕した緑饲料水分調整とカロリー源の補給 を目的として，これに生草重の $1 / 3$ 程度のデンブン范加 光（試験の一部にはデンプンを使用せず），さらに各種 の添加剂を添加混合した上でポリエチレン袋（詰込容量 $1 \mathrm{~kg}$ と $25 \mathrm{~kg} の 2$ 種）に固く詰め，結䇣後そのま李の 状態で，あるい性また加熱殺菌（70 8 $80^{\circ} \mathrm{C}$ の熱水中に て約 30 分間）処理をほどこした上で $3 \sim 4$ 週間窒温また は恒温 $\left(25^{\circ} \mathrm{C}\right)$ にて貯藏した。

これらの彆品の $\mathrm{pH}$, 有機酸舍量, フミ/熊案素なら びにアンモニア態穻素合量をそれぞれ測定するととも に，製品の一部については家鬼による消化試験ならびに 埕素の出納試験を行ない，その栄養洒值を比較検討し た.その結果はつぎの通りである。
秏ヶの添加威の中でホルマリン，フラゾリドンおよび ビロ亜硫酸ナトリウムは，サイレージの醇酵定抑制する のにかなりの効果があつた．しかしながら動物試験の結 果からは，ホルマリンならびにフランリドンの添加によ り製品の各成分の消化率ならび蛋白質の利用性が著し く低下することが明らかとなつた。一方ピロ西硫酸ナト

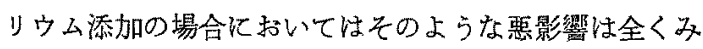
られなかつた。な报抗生物質添加の場合るサイレージの

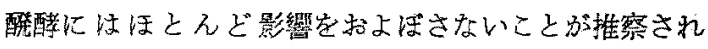
た.

また貯蔵前の加熱处理により有機酸の生成はかなり抑 制きれたが，蛋白質の消化率にはそれほどの影響はなか つた.

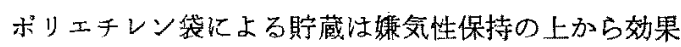
的であるように思われた。 